\title{
Austenite Grain Growth Behavior of 20Mn5 Steel Used for Heavy Hydro- Generator Shaft
}

\author{
M. Liu ${ }^{1}$ and Q. X. Ma \\ Department of Mechanical Engineering, Tsinghua University, Beijing, China \\ 1657056069@qq.com
}

УДК 539.4

\section{Рост аустенитных зерен в стали 20Mn5 для вала мощного гидрогенератора}

\author{
М. Лиу, К. К. Ма \\ Машиностроительный факультет, Университет Цинхуа, Пекин, Китай
}

Сталь 20Mn5 широко используется в производстве валов мощного гидрогенератора благодаря высокой прочности, пластичности и износостойкости. Некоторые исследователи отмечали явления деформирования при нагреве и рекристаллизаџии. Рост аустенитных зерен в стали при высокой температуре не изучен. Скорость роста зерен определяет их размеры 6 стальном слитке перед горячей ковкой, что существенно влияет на формирование микроструктуры. Образиы, вырезанные из полого слитка стали 20Mn5, нагревали до различных температур $\left(850,900,950,1000,1050,1100,1150\right.$ и 1200 ${ }^{\circ} \mathrm{C}$ с выдержкой в течение 1, 3, 5, 7, 9 и 11 ч перед закалкой в воде. Показано, что рост аустенитных зерен зависит от температуры и времени выдержки. В интервале температур $850 \ldots 1050^{\circ} \mathrm{C}$ скорость их роста мала, при температурах $1050 \ldots 1200^{\circ} \mathrm{C}$ она значительно увеличивается. Построена двухступенчатая модель роста зерен для прогнозирования их размеров после выдержки при высокой температуре. Прогнозируемые размеры аустенитных зерен хоромо согласуются с экспериментальными, что подтверждает надежность модели.

Ключевые слова: рост зерна, сталь 20Mn5, вал гидрогенератора, размер зерна, скорость роста.

Introduction. Long-time heating is carried out before the hot forging of heavy steel ingot. The heating temperature and holding time has a great influence on the initial grain size of heavy steel ingot before hot forging, thus affecting the microstructure evolution during hot forging and the mechanical properties of final products. Therefore, it's of great importance to study the evolution laws of austenite grain size under different temperature and holding time, and establish a mathematical model to predict the grain growth behavior. At present, the mathematical models to describe austenite grain growth are mainly divided into three categories: (i) the Beck dynamic relationship model describing grain growth under different holding times [1,2]; (ii) the Arrhenius relationship model describing grain growth under different heating temperatures [3, 4]; (iii) Sellars model, Anelli model, and Sellars-Anelli model describing grain growth under different heating temperatures and holding times [5-9]. The first two only give out the relationship between grain size and a single parameter, while the third kind of models comprehensively consider the effect of heating temperature and holding time on grain size, which have higher application value in practical engineering.

$20 \mathrm{Mn} 5$ steel has been widely used in the manufacture of hydro-generator shaft due to its good balance of strength, toughness, wear resistance and weldability. At present, there 
are very few researches on the deformation behaviors of $20 \mathrm{Mn} 5$ steel. Liu et al. [10, 11] investigated the rotatory deformation uniformity and compaction effect of $20 \mathrm{Mn} 5$ steel ingot, the results of which can provide important theoretical reference for establishment of forging process specification of hydro-generator shaft. However, there are no efforts taken to figure out the austenite grain growth laws of $20 \mathrm{Mn} 5$ steel. The steel ingot used for heavy hydro-generator shaft forging cools very slowly, causing the coarse grains to form in the steel ingot after solidification. Before hot forging, the heavy steel ingot is heated under high temperature for a long time, during which grain size increases to a large extent. Therefore, the heating temperature and holding time of the heating process greatly affects the microstructure evolution during hot forging, and reasonable heating temperature and holding time should be figured out to make sure that the heavy hydro-generator shaft forging with fine grains can be obtained after hot forging.

In this study, heat insulation experiments of $20 \mathrm{Mn} 5$ steel under different temperatures and holding times are carried out. And the austenite grain sizes under different heating conditions are measured to establish the mathematical model of austenite grain growth. The predicted grain sizes by the established model are in good agreement with the experimental ones, which indicates that the model is accurate and can provide reference for establishment of forging process of heavy hydro-generator shaft.

\section{Materials and Methods.}

1.1. Experimental Material. The cube samples with the length of $30 \mathrm{~mm}$ were taken from a $20 \mathrm{Mn} 5$ hollow steel ingot used for heavy hydro-generator shaft. The chemical composition of $20 \mathrm{Mn} 5$ steel is given in Table 1. Figure 1 shows the initial as-cast microstructure of $20 \mathrm{Mn} 5$ steel, which contains ferrite and pearlite.

Chemical Composition of 20Mn5 Steel (wt.\%)

\begin{tabular}{|c|c|c|c|c|c|c|c|c|}
\hline \hline $\mathrm{C}$ & $\mathrm{Si}$ & $\mathrm{Mn}$ & $\mathrm{P}$ & $\mathrm{S}$ & $\mathrm{Cr}$ & $\mathrm{Ni}$ & $\mathrm{Mo}$ & $\mathrm{Al}$ \\
\hline 0.24 & 0.26 & 1.47 & 0.0084 & 0.0020 & 0.15 & 0.076 & 0.020 & 0.015 \\
\hline
\end{tabular}

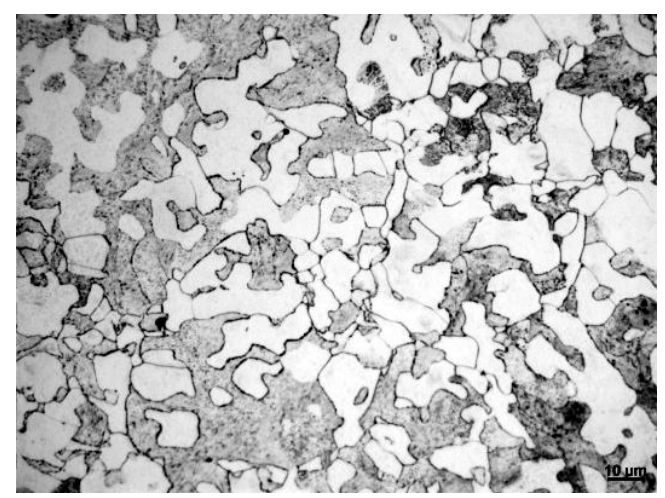

a

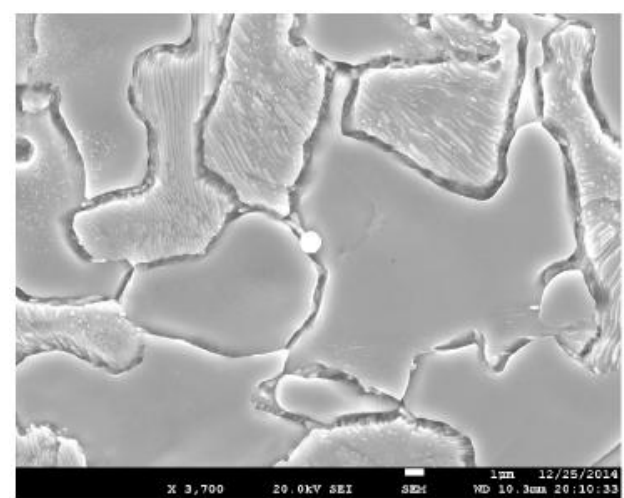

$\mathrm{b}$

Fig. 1. The initial as-cast microstructure of 20Mn5 steel: (a) optical micrograph; (b) SEM image.

1.2. Experimental Procedure. The grain growth experiments were carried out in a box-type resistance furnace. The detailed procedure is as follows: the samples were heated to different temperatures of $850,900,950,1000,1050,1100,1150$, and $1200^{\circ} \mathrm{C}$ at a heating rate of $15^{\circ} \mathrm{C} / \mathrm{min}$, and held for different times of $1,3,5,7,9$, and $11 \mathrm{~h}$. Finally the samples 
were quenched with water in order to retain the morphologies of austenite grains. After the heat insulation experiments, the samples were cut, ground, polished and etched in the mixture of $5 \mathrm{~g}$ picric acid, $4 \mathrm{~g}$ sodium dodecyl benzene sulfonate, and $100 \mathrm{ml}$ water at $60-70^{\circ} \mathrm{C}$. Then, the morphologies of emerged austenite grains were observed by OLYMPUS BX51 microscope. The average grain sizes were measured by linear intercept method according to ASTM E112 standard.

\section{Results and Discussion.}

2.1. Effect of Heating Temperature on Austenite Grain Growth Behavior. Figure 2 shows the austenite grains at different heating temperatures at a holding time of $5 \mathrm{~h}$. Obviously, the austenite grain size increases with the increasing temperatures, which indicates that the higher heating temperature results in larger growth rate of austenite grain. When heating temperature is not higher than $1000^{\circ} \mathrm{C}$, the change of the austenite grain size is small and the austenite grain size varies from $15.48 \mu \mathrm{m}$ at $850^{\circ} \mathrm{C}$ to $238.3 \mu \mathrm{m}$ at $1000^{\circ} \mathrm{C}$, as shown in Fig. 2a-d. Moreover, the grain boundaries at temperature not higher than $1000^{\circ} \mathrm{C}$ are curved; when heating temperature is higher than $1000^{\circ} \mathrm{C}$, the change of the austenite grain size is big and the austenite grain size varies from $302.93 \mu \mathrm{m}$ at $1050^{\circ} \mathrm{C}$ to $893.64 \mu \mathrm{m}$ at $1200^{\circ} \mathrm{C}$, as shown in Fig. $2 \mathrm{e}-\mathrm{h}$. In addition, the grain boundaries tend to be straight and the grain boundary angles tend to be $120^{\circ}$.

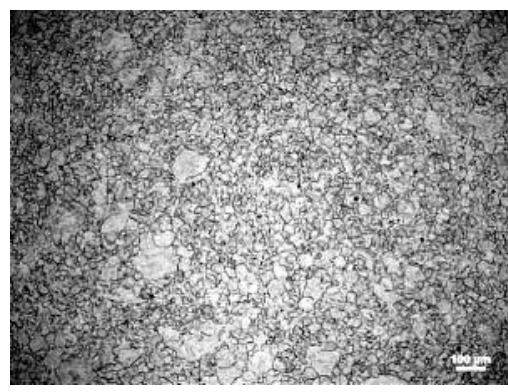

a

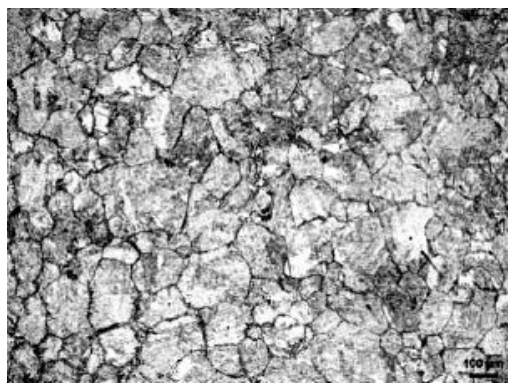

C

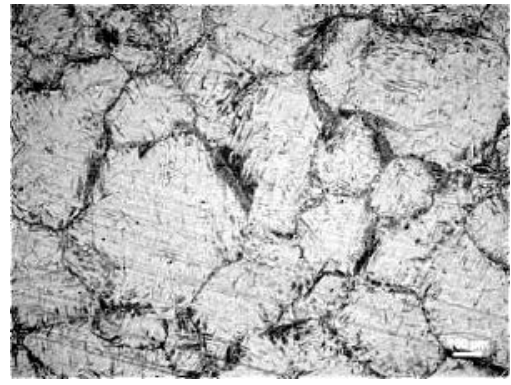

e

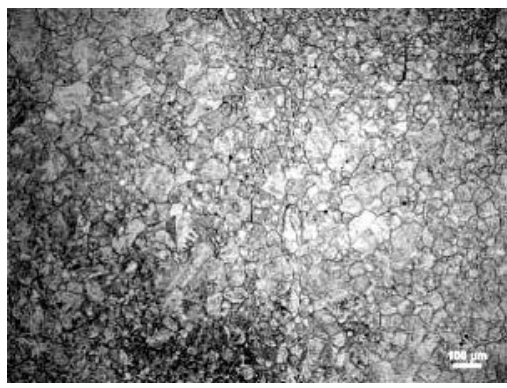

$\mathrm{b}$

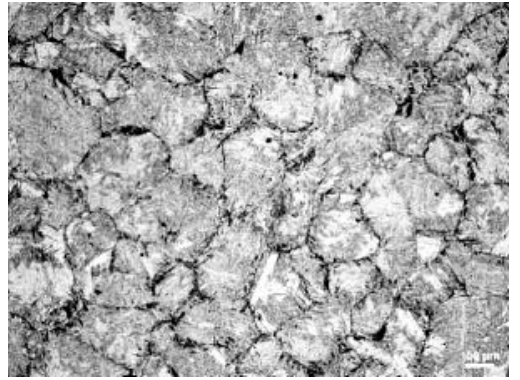

d

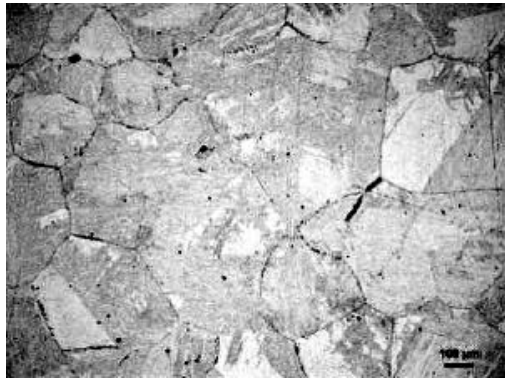

f 


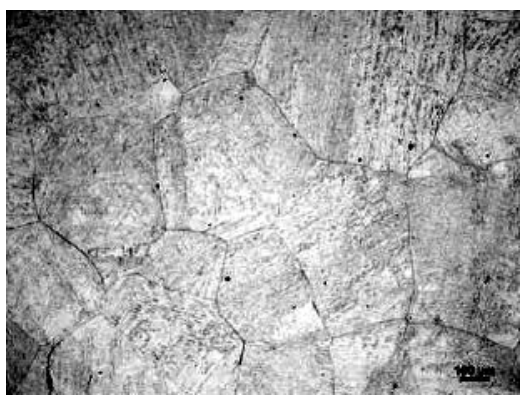

$\mathrm{g}$

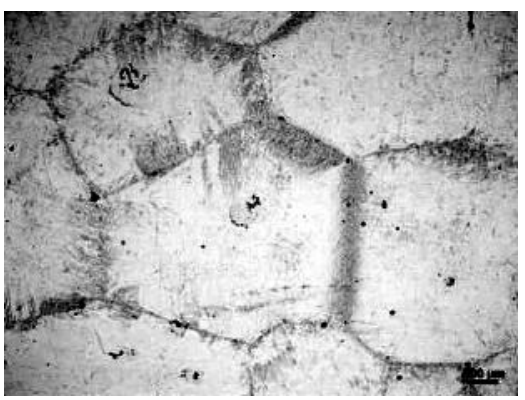

$\mathrm{h}$

Fig. 2. The austenite grains at a holding time of $5 \mathrm{~h}$ : (a) $850^{\circ} \mathrm{C}$; (b) $900^{\circ} \mathrm{C}$; (c) $950^{\circ} \mathrm{C}$; (d) $1000^{\circ} \mathrm{C}$; (e) $1050^{\circ} \mathrm{C}$; (f) $1100^{\circ} \mathrm{C}$; (g) $1150^{\circ} \mathrm{C}$; (h) $1200^{\circ} \mathrm{C}$.

Figure 3 shows the variation of grain size with heating temperature under different holding times. Obviously, under the same holding time, higher heating temperature results in larger grain size. When heating temperature is lower than $1050^{\circ} \mathrm{C}$, grain size increases slightly as the heating temperature increases; when heating temperature is above $1050^{\circ} \mathrm{C}$, grain size increases greatly as the heating temperature increases. As shown in Fig. 3, when holding time is $11 \mathrm{~h}$, the grain sizes corresponding to $850,900,950,1000,1050,1100$, 1150 , and $1200^{\circ} \mathrm{C}$ are $23.74,59.34,166.48,262.84,415.65,574.69,605.86$, and $1153.09 \mu \mathrm{m}$, respectively, which indicates the ability of $20 \mathrm{Mn} 5$ steel to resist grain coarsening is strong below $1050^{\circ} \mathrm{C}$.

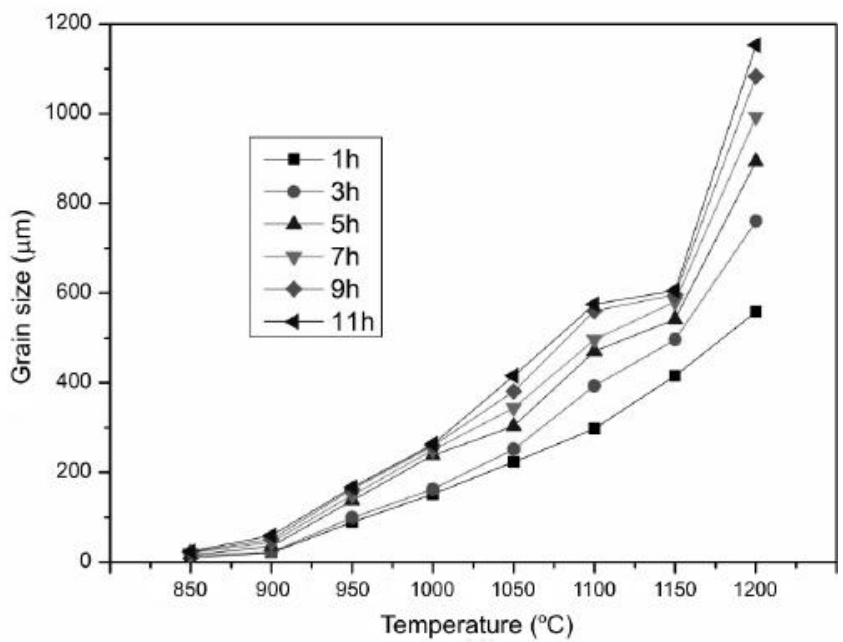

Fig. 3. The variation of grain size with heating temperature under different holding times.

2.2. Effect of Holding Time on Austenite Grain Growth Behavior. Figure 4 shows the austenite grains at different holding times at a heating temperature of $950^{\circ} \mathrm{C}$. Obviously, the grain size increases as the holding time increases. Figure 5 shows the variation of grain size with holding time under different heating temperatures. As shown in Fig. 5, at the same heating temperature, longer holding time results in larger grain size. And as the holding time increases, the growth rate of austenite grain tends to be smaller and smaller. And the corresponding explanation can be given as follows. According to [12], we have

$$
\left.\mu=K \exp \left[-Q_{m} / R T^{\prime}\right)\right](\sigma / D),
$$




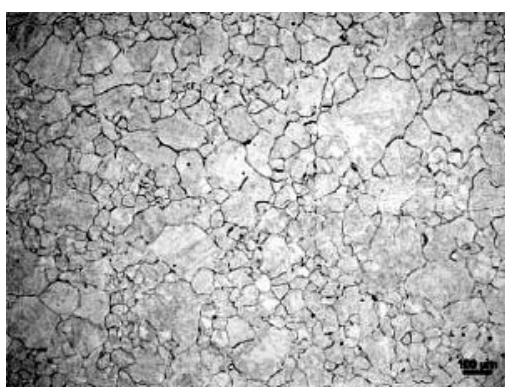

a

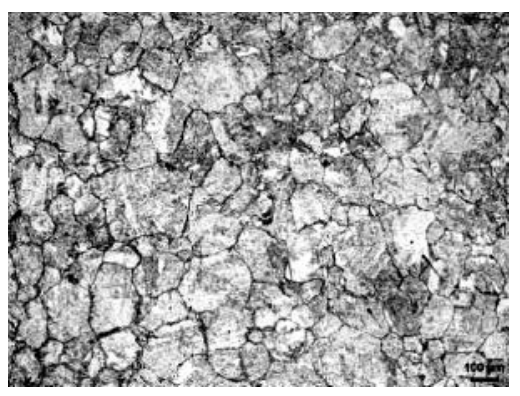

c

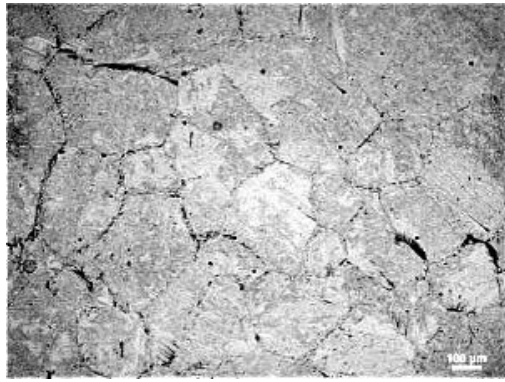

e

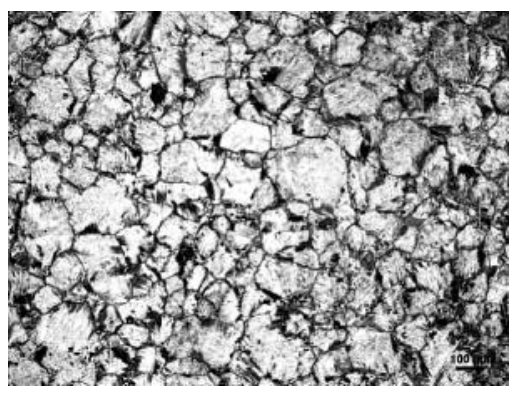

b

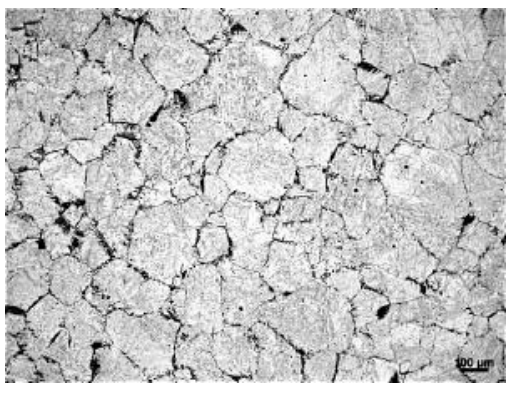

d

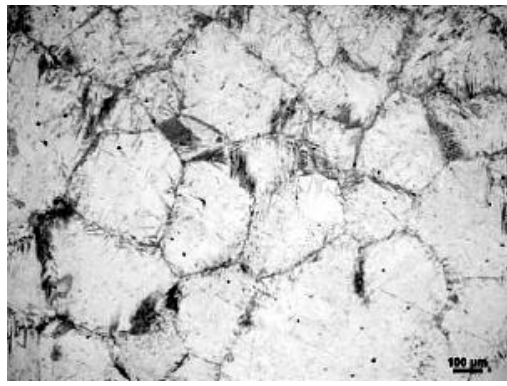

f

Fig. 4. The austenite grains at a heating temperature of $950^{\circ} \mathrm{C}$ : (a) $1 \mathrm{~h}$; (b) $3 \mathrm{~h}$; (c) $5 \mathrm{~h}$; (d) $7 \mathrm{~h}$; (e) 9 h; (f) $11 \mathrm{~h}$.

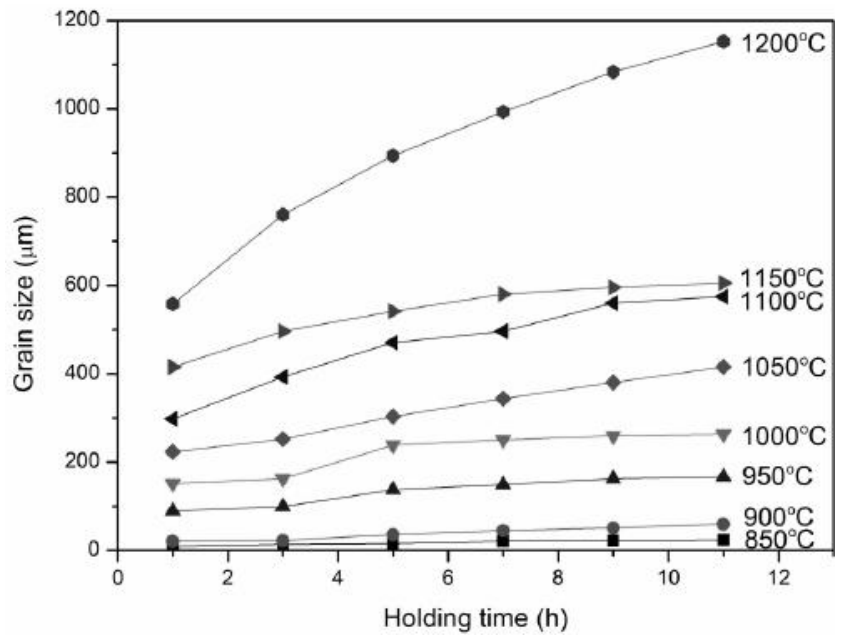

Fig. 5. The variation of grain size with holding time under different heating temperatures. 
where $\mu$ is the growth rate of austenite grain, $K$ is a constant, $Q_{m}$ is the movement activation energy of grain boundary, $R$ is gas constant, $T^{\prime}$ is absolute temperature, $\sigma$ is specific boundary energy, and $D$ is austenite grain size.

As the holding time increases, the austenite grain size increases. From Eq. (1), we can know that the growth rate of austenite grain decreases.

When heating temperature is below $1050^{\circ} \mathrm{C}$, the grain size increment is small as the holding time increases; while heating temperature is not lower than $1050^{\circ} \mathrm{C}$, the grain size increment is not able as the holding time increases. Therefore, $1050^{\circ} \mathrm{C}$ can be regarded as a transition temperature, above which grain has a strong tendency to be coarse. The reason why grain growth rate above $1050^{\circ} \mathrm{C}$ is larger than that below $1050^{\circ} \mathrm{C}$ can be given based on the second-phase particles. Usually, the second-phase particles in steel are dispersively distributed in matrix. When heating temperature is lower than the dissolution temperature of second-phase particles, second-phase particles are able to pin the austenite grain boundaries and prevent austenite grains from growing [13-15]. Figure 6 shows the morphology and energy dispersive spectrometer (EDS) spectrum of the second-phase particle in $20 \mathrm{Mn} 5$ steel. Figure $6 \mathrm{~b}$ shows the main elements of the second-phase particle at $850^{\circ} \mathrm{C}$ and $1 \mathrm{~h}$ include $\mathrm{Al}, \mathrm{Mg}$, and $\mathrm{O}$. As seen from Fig. 6d, the main elements of the second-phase particle at $900^{\circ} \mathrm{C}$ and $1 \mathrm{~h}$ include $\mathrm{Al}, \mathrm{Mg}$, and $\mathrm{O}$. And the second-phase particles, the main elements of which include $\mathrm{Al}, \mathrm{Mg}$, and $\mathrm{O}$, were also found at the other temperatures lower than $1050^{\circ} \mathrm{C}$. While at $1050,1100,1150$, and $1200^{\circ} \mathrm{C}$, no similar particles were found under the holding time of $1,3,5,7,9$, and $11 \mathrm{~h}$. Therefore, the dissolution temperature of the second-phase particles in $20 \mathrm{Mn} 5$ steel can be considered to be about $1050^{\circ} \mathrm{C}$. The above results about the second-phase particle can give a reasonable explanation for the different grain growth rates at different temperature stages.

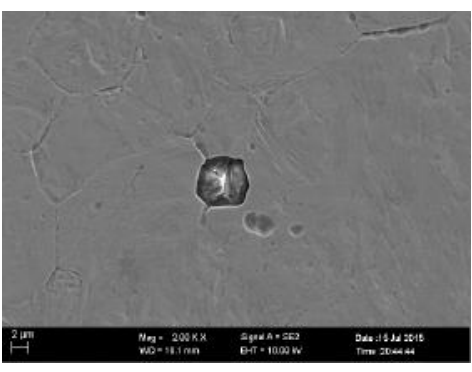

a

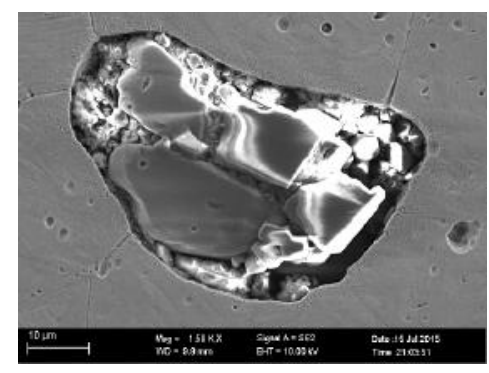

c

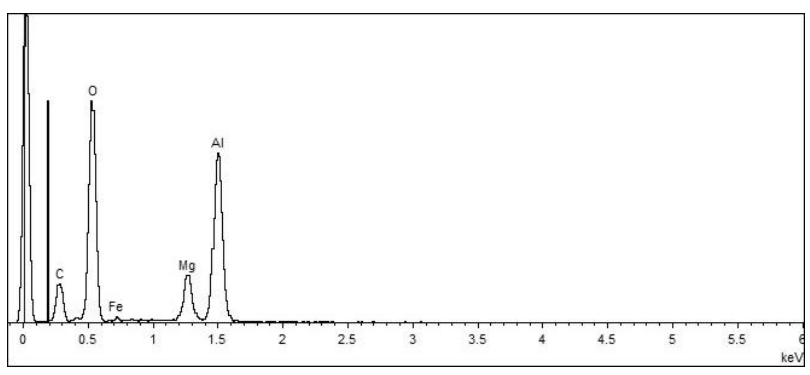

b

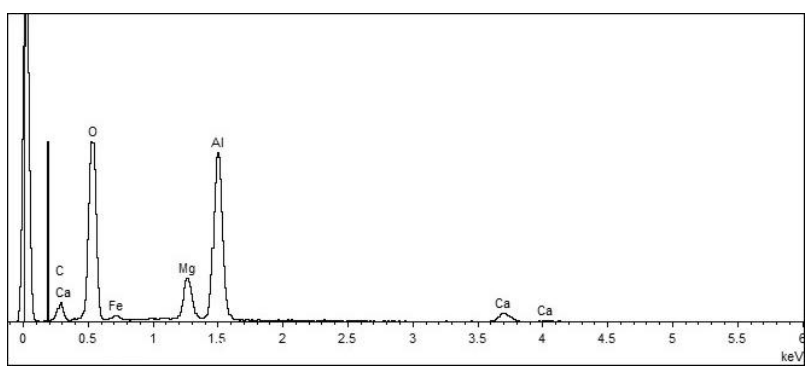

d

Fig. 6. The morphology and EDS spectrum of the second-phase particle in $20 \mathrm{Mn} 5$ steel: (a) morphology at $850^{\circ} \mathrm{C}$ and $1 \mathrm{~h}$; (b) EDS spectrum at $850^{\circ} \mathrm{C}$ and $1 \mathrm{~h}$; (c) morphology at $900^{\circ} \mathrm{C}$ and $1 \mathrm{~h}$; (d) EDS spectrum at $900^{\circ} \mathrm{C}$ and $1 \mathrm{~h}$.

3. Austenite Grain Growth Model of 20Mn5 Steel. The above experimental results show that $1050^{\circ} \mathrm{C}$ can be regarded as a transition temperature, above which grain has a strong tendency to be coarse, and the austenite grain growth processes at different 
temperature stages are different. Therefore, two austenite grain growth models are established based on the experimental data of two temperature stages $(850,900,950$, and $1000^{\circ} \mathrm{C} ; 1050,1100,1150$, and $1200^{\circ} \mathrm{C}$ ). The austenite grain growth model proposed by Anelli is written as follows [16-19]:

$$
\left.D=A t^{m^{\prime}} \exp \left[-Q_{g g} / R T^{\prime}\right)\right]
$$

where $D$ is austenite grain size $(\mu \mathrm{m}), t$ is holding time $(\mathrm{h}), Q_{g g}$ is the activation energy of grain growth $(\mathrm{J} / \mathrm{mol}), R$ is gas constant $[8.314 \mathrm{~J} /(\mathrm{mol} \cdot \mathrm{K})], T^{\prime}$ is absolute temperature $(\mathrm{K})$, and $A$ and $m^{\prime}$ are constants.

In this study, the austenite grain growth model proposed by Anelli was adopted. Taking the natural logarithms of both sides of Eq. (2) gives:

$$
\ln D=\ln A+m^{\prime} \ln t-Q_{g g} /\left(R T^{\prime}\right) .
$$

Based on the experimental data at $850,900,950$, and $1000^{\circ} \mathrm{C}$, the variation of $\ln D$ with $\ln t$ at different temperatures $\left(850,900,950\right.$, and $\left.1000^{\circ} \mathrm{C}\right)$ is presented in Fig. 7 . Figure 8 shows the variation of $\ln D$ with $-10000 /\left(R T^{\prime}\right)$ at different holding times. In Fig. 7, at a certain temperature, the slope of the fitting line equals $m^{\prime}$. The value of $m^{\prime}$ can be obtained by taking the average value of different slopes. In Fig. 8, at a certain holding time, the slope of the fitting line equals $Q_{g g} / 10000$ and the intercept of the fitting line equals $\ln A+m^{\prime} \ln t$. The values of $Q_{g g}$ and $A$ can be obtained by taking the average values of $Q_{g g}$ and $A$ at different holding times.

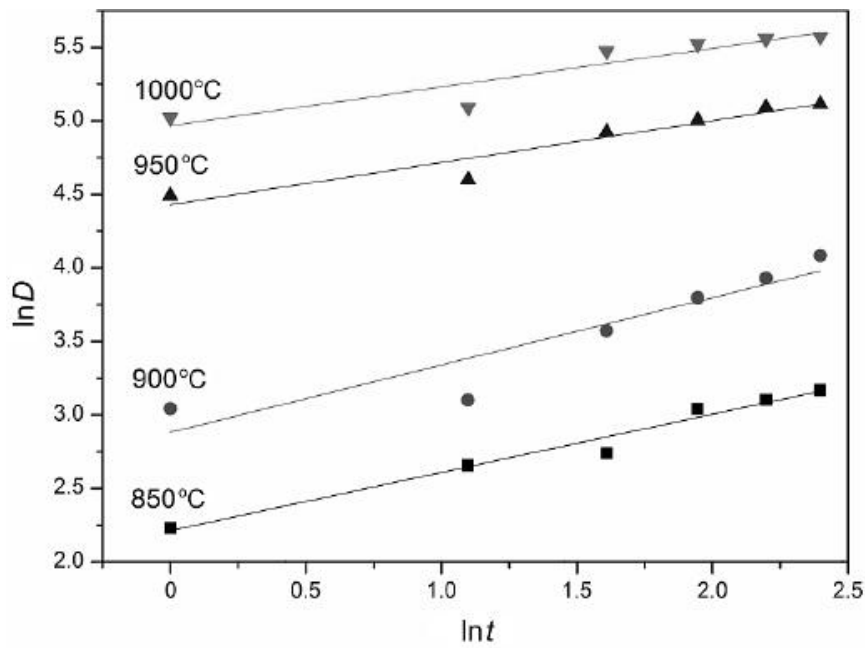

Fig. 7. The variation of $\ln D$ with $\ln t$ at different heating temperatures.

From the fitting results of Figs. 7 and $8, m^{\prime}=0.350483, Q_{g g}=212630.4833 \mathrm{~J} / \mathrm{mol}$, and $A=1.83636 \cdot 10^{11}$ can be obtained. Therefore, the austenite grain growth model at 850 , 900,950 , and $1000^{\circ} \mathrm{C}$ can be given as follows:

$$
D=1.83636 \cdot 10^{11} t^{0.350483} \exp \left[-212630.4833 /\left(R T^{\prime}\right)\right] .
$$

However, Eq. (4) fails to give an accurate prediction of the austenite grain size at different heating conditions. There exists a large deviation between the measured grain size 


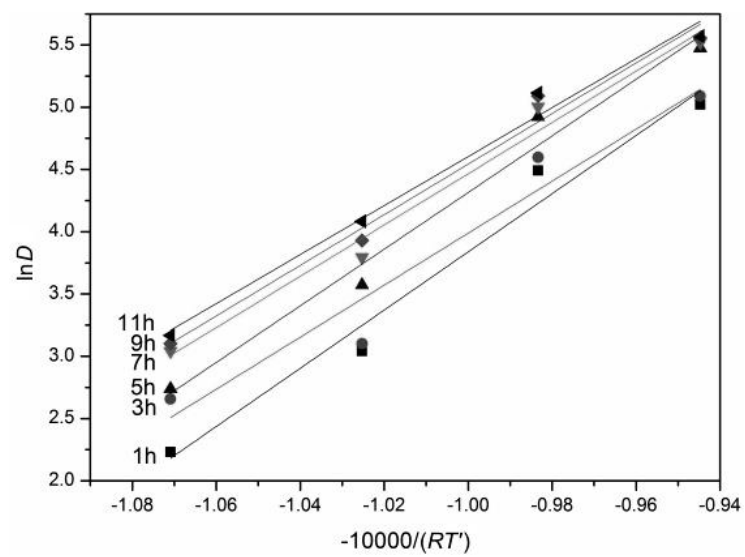

Fig. 8. The variation of $\ln D$ with $-10000 /\left(R T^{\prime}\right)$ at different holding times.

and calculated grain size on some heating conditions. And a method using polynomial fitting is proposed to revise the austenite grain growth model shown in Eq. (4). Figure 9 shows the polynomial fitting results at $850,900,950$, and $1000^{\circ} \mathrm{C}$.

Thus, according to the polynomial fitting results, the revised austenite grain growth model at $850,900,950$, and $1000^{\circ} \mathrm{C}$ can be given as follows:

$$
\begin{aligned}
D= & -13.11727+0.62646\left\{1.83636 \cdot 10^{11} t^{0.350483} \exp \left[-212630.4833 /\left(R T^{\prime}\right)\right]\right\}- \\
& -4.80738 \cdot 10^{-4}\left\{1.83636 \cdot 10^{11} t^{0.350483} \exp \left[-212630.4833 /\left(R T^{\prime}\right)\right]\right\}^{2}+ \\
+ & 1.66241 \cdot 10^{-7}\left\{1.83636 \cdot 10^{11} t^{0.350483} \exp \left[-212630.4833 /\left(R T^{\prime}\right)\right]\right\}^{3}
\end{aligned}
$$

Based on Eq. (5), grain sizes at different heating temperatures and holding times are solved out. And the measured grain sizes and the calculated grain sizes at 850, 900, 950, and $1000^{\circ} \mathrm{C}$ are presented in Fig. 10. Figure 10 shows that the calculated grain sizes are in good agreement with the measured grain sizes, which indicates the established austenite grain growth model at $850,900,950$, and $1000^{\circ} \mathrm{C}$ is reliable and has a relatively high accuracy.

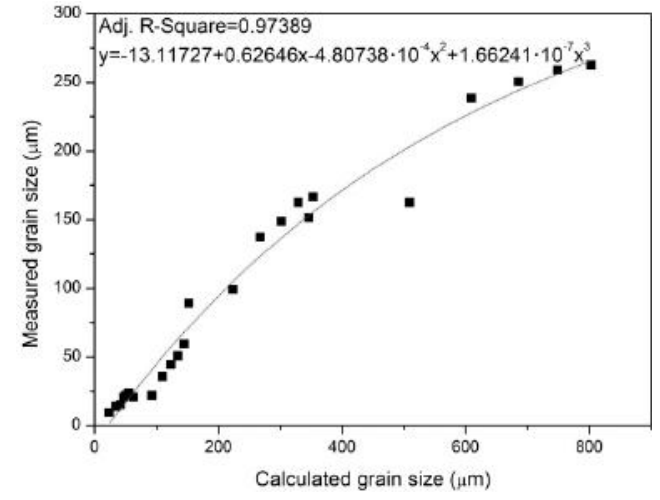

Fig. 9

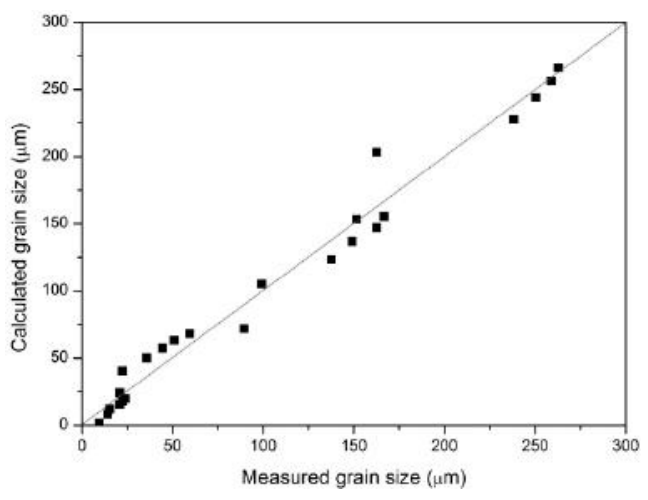

Fig. 10

Fig. 9. The polynomial fitting results at $850,900,950$, and $1000^{\circ} \mathrm{C}$.

Fig. 10. The measured grain sizes and calculated grain sizes at $850,900,950$, and $1000^{\circ} \mathrm{C}$. 
Based on the experimental data at $1050,1100,1150$, and $1200^{\circ} \mathrm{C}$, the variation of $\ln D$ with $\ln t$ at different temperatures $\left(1050,1100,1150\right.$, and $\left.1200^{\circ} \mathrm{C}\right)$ is presented in Fig. 11 . Figure 12 shows the variation of $\ln D$ with $-10000 /\left(R T^{\prime}\right)$ at different holding times. In Fig. 11, at a certain temperature, the slope of the fitting line equals $m^{\prime}$. The value of $m^{\prime}$ can be obtained by taking the average value of different slopes. In Fig. 12, at a certain holding time, the slope of the fitting line equals $Q_{g g} / 10000$ and the intercept of the fitting line equals $\ln A+m^{\prime} \ln t$. The values of $Q_{g g}$ and $A$ can be obtained by taking the average values of $Q_{g g}$ and $A$ at different holding times.

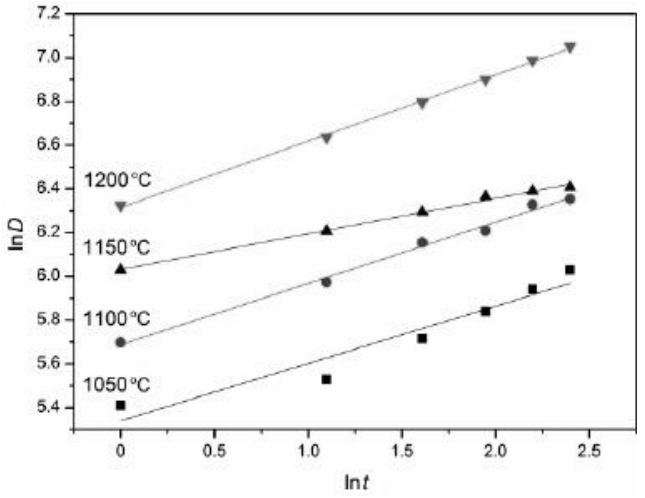

Fig. 11

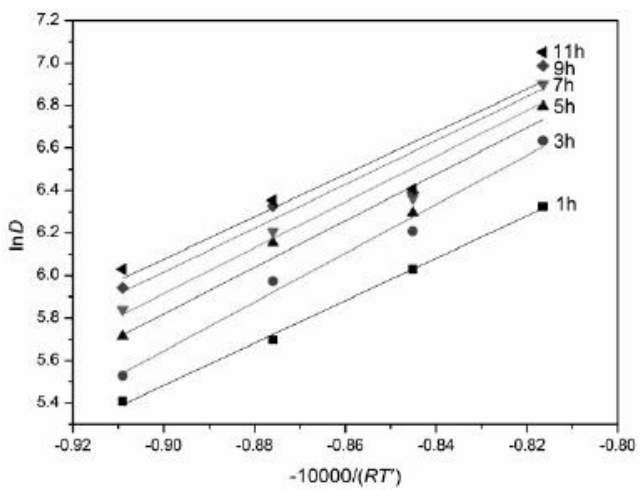

Fig. 12

Fig. 11. The variation of $\ln D$ with $\ln t$ at different heating temperatures.

Fig. 12. The variation of $\ln D$ with $-10000 /\left(R T^{\prime}\right)$ at different holding times.

From the fitting results of Figs. 11 and 12, $m^{\prime}=0.2517, Q_{g g}=105919.3 \mathrm{~J} / \mathrm{mol}$, and $A=3525405$ can be obtained. Therefore, the austenite grain growth model at 1050, 1100, 1150 , and $1200^{\circ} \mathrm{C}$ can be given as follows:

$$
D=3525405 t^{0.2517} \exp \left[-105919.3 /\left(R T^{\prime}\right)\right] .
$$

However, Eq. (6) can't give an accurate prediction of the austenite grain size at different heating conditions. There exists some unneglectable deviations between the measured grain size and calculated grain size on some heating conditions. And a method using polynomial fitting is proposed to revise the austenite grain growth model shown in Eq. (6). Figure 13 shows the polynomial fitting results at $1050,1100,1150$, and $1200^{\circ} \mathrm{C}$.

Thus, according to the polynomial fitting results, the revised austenite grain growth model at $1050,1100,1150$, and $1200^{\circ} \mathrm{C}$ can be given as follows:

$$
\begin{gathered}
D=-252.45733+2.58233\left\{3525405 t^{0.2517} \exp \left[-105919.3 /\left(R T^{\prime}\right)\right]\right\}- \\
\quad-0.00329\left\{3525405 t^{0.2517} \exp \left[-105919.3 /\left(R T^{\prime}\right)\right]\right\}^{2}+ \\
+1.88493 \cdot 10^{-6}\left\{3525405 t^{0.2517} \exp \left[-105919.3 /\left(R T^{\prime}\right)\right]\right\}^{3}
\end{gathered}
$$

Based on Eq. (7), grain sizes at different heating temperatures and holding times are solved out. And the measured grain sizes and the calculated grain sizes at 1050, 1100, 1150 , and $1200^{\circ} \mathrm{C}$ are presented in Fig. 14. Figure 14 shows that the calculated grain sizes are in good agreement with the measured grain sizes, which indicates the established 


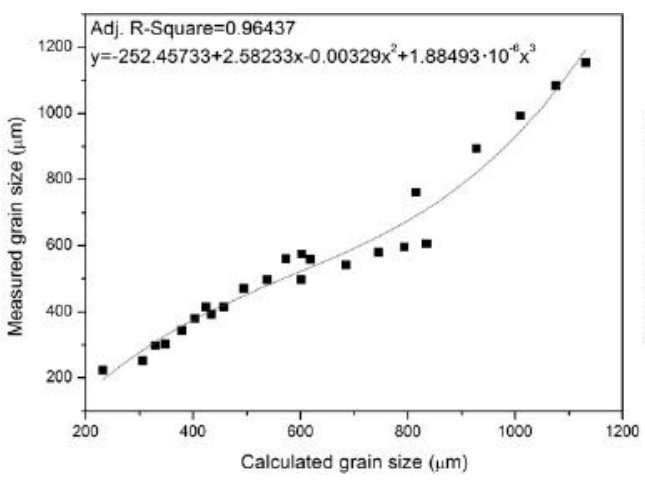

Fig. 13

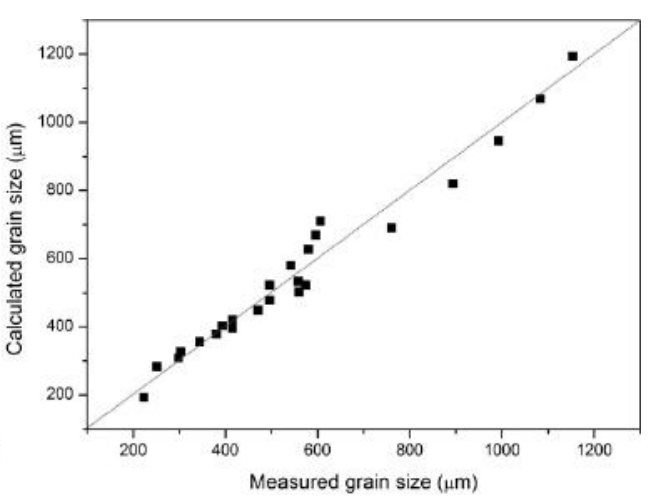

Fig. 14

Fig. 13. The polynomial fitting results at $1050,1100,1150$, and $1200^{\circ} \mathrm{C}$.

Fig. 14. The measured grain sizes and calculated grain sizes at $1050,1100,1150$, and $1200^{\circ} \mathrm{C}$.

austenite grain growth model at $1050,1100,1150$, and $1200^{\circ} \mathrm{C}$ is reliable and has a relatively high accuracy.

Table 2 shows the measured grain sizes and calculated grain sizes on different heating conditions. Table 3 gives out the absolute value of relative error on different heating conditions. For the austenite grain growth model at $850,900,950$, and $1000^{\circ} \mathrm{C}$, the average absolute value of relative error is $21.45 \%$. And the absolute value of relative error is defined by Eq. (8):

$$
A V R E=\left|\frac{C G S-M G S}{M G S}\right|
$$

where AVRE is the absolute value of relative error, CGS is the calculated grain size, and $M G S$ is the measured grain size.

$\mathrm{T}$ a b 1 e 2

Measured Grain Sizes $(\mu \mathrm{m})$ and Calculated Grain Sizes $(\mu \mathrm{m})$ on Different Heating Conditions

\begin{tabular}{|c|c|c|c|c|c|c|c|c|c|c|c|c||}
\hline \hline \multirow{2}{*}{$\begin{array}{c}T, \\
{ }^{\circ} \mathrm{C}\end{array}$} & \multicolumn{2}{|c|}{$1 \mathrm{~h}$} & \multicolumn{2}{c|}{$3 \mathrm{~h}$} & \multicolumn{2}{c|}{$5 \mathrm{~h}$} & \multicolumn{2}{c|}{$7 \mathrm{~h}$} & \multicolumn{2}{c|}{$9 \mathrm{~h}$} & \multicolumn{2}{c|}{$11 \mathrm{~h}$} \\
\cline { 2 - 15 } & MGS & CGS & MGS & CGS & MGS & CGS & MGS & CGS & MGS & CGS & MGS & CGS \\
\hline 850 & 9.3 & 1.5 & 14.2 & 8.1 & 15.5 & 12.2 & 20.9 & 15.2 & 22.3 & 17.7 & 23.7 & 19.9 \\
\hline 900 & 20.9 & 24.2 & 22.3 & 40.5 & 35.6 & 50.2 & 44.5 & 57.3 & 50.9 & 63.2 & 59.3 & 68.1 \\
\hline 950 & 89.4 & 71.8 & 99.3 & 105.0 & 137.5 & 123.5 & 148.9 & 136.7 & 162.5 & 147.0 & 166.5 & 155.6 \\
\hline 1000 & 151.5 & 153.2 & 162.5 & 203.2 & 238.3 & 227.7 & 250.3 & 244.0 & 259.0 & 256.2 & 262.8 & 266.1 \\
\hline 1050 & 223.4 & 193.4 & 251.7 & 284.1 & 302.9 & 327.7 & 343.7 & 356.7 & 380.3 & 378.4 & 415.6 & 395.8 \\
\hline 1100 & 297.9 & 309.2 & 392.8 & 403.9 & 470.3 & 448.8 & 496.5 & 479.3 & 560.3 & 503.1 & 574.7 & 523.1 \\
\hline 1150 & 415.6 & 421.0 & 496.5 & 522.6 & 541.6 & 580.3 & 580.3 & 627.3 & 595.8 & 669.9 & 605.9 & 710.2 \\
\hline 1200 & 558.5 & 533.9 & 760.5 & 690.9 & 893.6 & 820.4 & 992.9 & 945.5 & 1083.2 & 1069.4 & 1153.1 & 1192.9 \\
\hline \hline
\end{tabular}

For the austenite grain growth model at $1050,1100,1150$, and $1200^{\circ} \mathrm{C}$, the average absolute value of relative error is $6.67 \%$. The above results further validate the high reliability of the established austenite grain growth models at two temperature stages. 
$\mathrm{T}$ a b 1 e 3

Absolute Value of Relative Error (\%) on Different Heating Conditions

\begin{tabular}{||c|c|c|c|c|c|c||}
\hline$T,{ }^{\circ} \mathrm{C}$ & $1 \mathrm{~h}$ & $3 \mathrm{~h}$ & $5 \mathrm{~h}$ & $7 \mathrm{~h}$ & $9 \mathrm{~h}$ & $11 \mathrm{~h}$ \\
\hline 850 & 84.32 & 42.94 & 21.46 & 27.39 & 20.40 & 16.31 \\
\hline 900 & 15.68 & 82.17 & 40.92 & 28.84 & 24.17 & 14.75 \\
\hline 950 & 19.63 & 5.75 & 10.20 & 8.25 & 9.52 & 6.56 \\
\hline 1000 & 1.10 & 25.08 & 4.44 & 2.51 & 1.09 & 1.23 \\
\hline 1050 & 13.41 & 12.86 & 8.19 & 3.78 & 0.49 & 4.78 \\
\hline 1100 & 3.79 & 2.83 & 4.59 & 3.47 & 10.21 & 8.98 \\
\hline 1150 & 1.30 & 5.27 & 7.15 & 8.10 & 12.44 & 17.23 \\
\hline 1200 & 4.40 & 9.16 & 8.20 & 4.78 & 1.28 & 3.46 \\
\hline
\end{tabular}

\section{Conclusions}

1. The austenite grain size increases with the heating temperature and holding time.

2. As the holding time increases, the growth rate of austenite grain decreases.

3. When heating temperature is below $1050^{\circ} \mathrm{C}$, the grain size increment is small as the holding time increases; while heating temperature is not lower than $1050^{\circ} \mathrm{C}$, the grain size increment is notable as the holding time increases. $1050^{\circ} \mathrm{C}$ can be regarded as a transition temperature, above which grain has a strong tendency to be coarse.

4. Two austenite grain growth models are established based on the experimental data of two temperature stages $\left(850,900,950\right.$, and $1000^{\circ} \mathrm{C} ; 1050,1100,1150$, and $\left.1200^{\circ} \mathrm{C}\right)$. The calculated grain sizes are in good agreement with the measured grain sizes, which indicates the established austenite grain growth model is reliable and has a relatively high accuracy.

\section{Резиме}

Сталь 20Mn5 широко використовується у виробництві валів потужного гідрогенератора завдяки високій міцності, пластичності та зносостійкості. Деякі дослідники відмічали явища деформування при нагріванні і рекристалізації. Ріст аустенітних зерен у сталі за високої температури не вивчався. Швидкість росту зерен визначає їх розміри в стальному злитку перед гарячим куванням, що суттєво впливає на формування мікроструктури. Зразки 3 порожнистого злитка сталі 20Mn5 нагрівали до різних температур $\left(850,900,950,1000,1050,1100,1150\right.$ i $\left.1200^{\circ} \mathrm{C}\right)$ із витримкою протягом 1, 3, 5, 7, 9 та 11 годин перед закалюванням у воді. Показано, що ріст аустенітних зерен залежить від температури і часу витримки. В інтервалі температур $850 \ldots 1050^{\circ} \mathrm{C}$ швидкість їх росту мала, за температур $1050 \ldots 1200^{\circ} \mathrm{C}$ вона значно збільшується. Побудовано двоступеневу модель росту зерен для прогнозу їх розмірів після витримки за високої температури. Прогнозовані розміри аустенітних зерен добре узгоджуються з експериментальними, що підтверджує надійність моделі.

1. P. A. Beck, J. C. Kremer, L. J. Demer, and M. L. Holzworth, "Grain growth in high-purity aluminum and in an aluminum-magnesium alloy," Trans. AIME, 175, 372-400 (1948).

2. P. A. Beck, M. L. Holzworth, and H. Hu, "Instantaneous rates of grain growth," Phys. Rev., 73, 526-527 (1948). 
3. D. Turnbull, "Theory of grain boundary migration rates," Trans. AIME, 191, 661-665 (1951).

4. M. Hillert, "On the theory of normal and abnormal grain growth," Acta. Metall., 13, No. 3, 227-238 (1965).

5. C. M. Sellars and J. A. Whiteman, "Recrystallization and grain growth in hot rolling," Met. Sci., 13, 187-194 (1979).

6. E. Anelli, "Application of mathematical modelling to hot rolling and controlled cooling of wire rods and bars," ISIJ Int., 32, 440-449 (1992).

7. N. Raghunathan and T. Sheppard, "Microstructural development during annealing of hot rolled Al-Mg alloys," Mater. Sci. Technol., 5, 542-547 (1989).

8. L. Q. Chen, F. L. Sui, and X. H. Liu, "Grain growth model of inconel 718 alloy forged slab in reheating process prior to rough rolling," Acta. Metall. Sin., 45, 12421248 (2009).

9. Y. W. Xu, D. Tang, Y. Song, and X. G. Pan, "Prediction model for the austenite grain growth in a hot rolled dual phase steel," Mater. Design, 36, 275-278 (2012).

10. M. Liu and Q. X. Ma, "Research on rotatory deformation uniformity and compaction effect of super-heavy hollow steel ingot," J. Mech. Eng., 52, 90-96 (2016).

11. M. Liu, X. L. Dong, and Q. X. Ma, "Investigation on hollow steel ingot forging process of heavy cylinder forging," J. Plast. Eng., 20, 1-8 (2013).

12. W. M. Mao and X. B. Zhao, Recrystallization and Grain Growth of Metal [in Chinese], Metallurgical Industry Press, Beijing, China (1994).

13. Q. L. Yong, The Second Phase in Steel [in Chinese], Metallurgical Industry Press, Beijing, China (2006).

14. H. Pous-Romero, I. Lonardelli, D. Cogswell, and H. K. D. H. Bhadeshia, "Austenite grain growth in a nuclear pressure vessel steel," Mater. Sci. Eng. A, 567, 72-79 (2013).

15. B. J. Lee, H. D. Kim, and J. H. Hong, "Calculation of $\alpha / \gamma$ equilibria in SA508 grade 3 steels for intercritical heat treatment," Metall. Mat. Trans. A, 29, 1441-1447 (1998).

16. L. N. Duan, J. M. Wang, Q. Y. Liu, et al., "Austenite grain growth behavior of X80 pipeline steel in heating process," J. Iron Steel Res. Int., 17, 62-66 (2010).

17. W. Li and K. Xia, "Kinetics of the $\alpha$ grain growth in a binary Ti-44Al alloy and a ternary Ti-44Al-0.15Gd alloy," Mater. Sci. Eng. A, 329-331, 430-434 (2002).

18. S. S. Zhang, M. Q. Li, Y. G. Liu, et al., "The growth behavior of austenite grain in the heating process of 300M steel," Mater. Sci. Eng. A, 528, 4967-4972 (2011).

19. C. X. Yue, L. W. Zhang, S. L. Liao, and H. J. Gao, "Kinetic analysis of the austenite grain growth in GCr15 steel," J. Mater. Eng. Perform., 19, 112-115 (2010). 